\title{
INDICATORS OF STUDENTS' SATISFACTION OF QUALITY EDUCATION SERVICES IN SOME SELECTED UNIVERSITIES IN GHANA
}

\author{
I. Amoako* \\ e-mail: isaac.amoako2@stu.ucc.edu.gh \\ K. Asamoah-Gyimah* \\ e-mail: kasamoah-gyimah@ucc.edu.gh \\ *Department of Education and Psychology \\ University of Cape Coast \\ Cape Coast, Ghana
}

\section{ABSTRACT}

Enhancing quality of educational services in higher education is an issue of concern for all stakeholders of education in the $21^{\text {st }}$ Century. Students' assessment of educational services are often seen as an efficient tool for improving quality of teaching and learning in tertiary schools. The aim of the study was to investigate factors that contribute to students' satisfaction of education services as a quality assurance module for universities.

A descriptive cross-sectional survey design was used for the investigation. Following a multistage sampling procedure, 1500 students were sampled from three public universities in Ghana. Student satisfaction (SS) and Quality assurance questionnaire (QAQ) for students were developed to measure satisfaction of students related to the educational services that they receive in their campuses. Covariance-Based structural equation modeling, specifically, Analysis of Moment Structures (AMOS) was used to validate the instrument and to test the study hypotheses. Findings of the study revealed that "instructional environment", "technological environment" and "psychological environment" were predictors of students' satisfaction in the context of how students see academic institution to be quality centered. The study recommended that universities in Ghana should emphasize and prioritize students' satisfaction in their quality assurance framework as a way of sustaining quality provision of educational services.

Keywords: predictors, quality, satisfaction, stakeholders, environment

\section{INTRODUCTION}

In this $21^{\text {st }}$ century, there is a vehement demand for quality educational services by stakeholders of education all over the world (McRoy and Gibbs 2009). Kazeroony (2012), opined that a lot of factors do explain the need for restructuring strategies for quality education provision. The factors included the ever-changing characteristics of learners, technological advancement, 
economic reasons, to mention but a few. Contemporary universities are changing day by day to be able to efficiently deal with the worlds numerous challenges (Wissema 2009). Improving learning is still considered the primary aim of universities. The management and student body of academic institutions have functions to perform in the overall achievement of the university's aim (Bush 2011).

Most academic institutions around the world have seen significant transformation because of the public demand for quality services (Bernhard 2012). In this light, competitive strategies toward quality education service provision can be developed consciously. This is achieved by the integration of quality education service plan into the overall institutional management framework (Kettunen 2011). In client-centered educational approach, it is only meaningful that quality educational service provision is very crucial. Taking the university as an organization, students, parents and the society as a whole form the clientele for which all quality services are directed (Sharma and Kamath 2006). And so, the only way found to improve the foregoing stakeholders' confidence in the education system is through robust quality assurance systems (Kettunen 2008).

Today's students have numerous expectations that range from choosing what to learn, how to learn and how much to learn based on their peculiar individual academic needs (Stråhlman 2012). Students' assessment of services in the school can be seen as one of the internal quality assurance tools used for enhancement of quality academic environment. Kara and DeShields (2004) intimated that academic institutions that acknowledge the significance of students' assessment of quality services, in most cases would satisfy students' academic needs to a very large extent. Quality assurance as a concept in the academia largely refers to operations in which university standards, of teaching and learning are improved. This definition of quality assurance is in line with the overall objective of education, that is, to advance knowledge.

In Ghana, the establishment of National Council for Tertiary Education (NCTE) in 1993 by an Act of Parliament (Act 454) was purposely to advance quality, impartial access, appropriateness, practicable funding, right governance and outstanding management in tertiary education that promote national development. Further, the nation in the same year of 1993 established the National Accreditation Board (NAB) through the passage of the NAB Law (PNDCL 317). The institution was designed to advance the course of appropriate management of tertiary schools as a quality promotion agency. In addition to established standards by institutions such as NAB and NCTE, universities have their internal quality assurance policies that ensure that quality services are delivered (Seniwoliba 2014). Several attempts have been made by various public universities in Ghana toward improving quality within the universities. In line with the move to improve quality in universities in Ghana, thorough investigation 
regarding students' role and satisfaction of educational services have not being adequately explored. This study is built on this premise.

\section{STATEMENT OF THE PROBLEM}

University education is one of the facilitators of national development for all economies (Peretomode 2008). World Bank (2004) preaches that university education is the bedrock for progression in economic, political and industrial phases of nations around the world. Knowledge that is generated in the universities and other tertiary institutions become the resources for turning the fortunes of the country from worse to better economy. To be in alignment with the foregoing status, the Ghana National Accreditation Board was established to monitor the internal sustainable arrangement that would ensure quality educational provision in the country (Seniwoliba 2014). In Ghana, numerous empirical studies have been done, specifically, on quality assurance practices of universities over the past three decades (Seniwoliba and Yakubu 2015). Most of the studies done, focused attention on how the term quality could be defined (Tsevi 2014), the design and relevance of various national quality assurance schemes (Badu-Nyarko 2013), academic quality assurance practices (Ofosu and Fredua-Kwarteng 2018; Seniwoliba 2014), barriers to internal quality assurance (Boateng 2014) and analysis of quality assurance policies (Seniwoliba and Yakubu 2015). The foregoing studies suggest that administrators of Ghanaian universities are seriously implementing quality assurance policies, however, the question of what factors determine students' satisfaction for quality educational services remain unanswered. This is because needed attention has not been paid to the investigation of what explains students' satisfaction of education services within the Ghanaian setting. In order to provide empirical data to contribute to policy and also address the gap in literature, factors that determine students' satisfaction of educational services were the main concerns of this study. In connection with the main objective, one research question and a hypothesis guided the study.

\section{Research question}

1. What is the level of students' satisfaction of educational services?

\section{Research hypothesis}

$\mathrm{H}_{0}$ : Technological, instructional and psychological environment does not significantly predict students' satisfaction of educational services.

$\mathrm{H}_{1}$ : Technological, instructional and psychological environment significantly predict students' satisfaction of educational services. 


\section{LITERATURE REVIEW}

\section{Students' satisfaction of educational services}

Many empirical studies have been done on what seems to contribute to student satisfaction of educational services, for example, Douglas, Douglas and Barnes (2006) worked on quality assurance practices of universities in England and found out that school resources quality was not significant in explaining satisfaction of students. In contrast, Encabo (2011) investigation in Philippines revealed quality of academic resources to be the sole predicting indicator of satisfaction among students. Arambewela and Hall (2009) also worked on the same subject and found out that teaching style of lecturers affected university students' satisfaction. In addition, they further discovered that students' satisfaction was significantly related to services such as; provision of innovative knowledge, lecturers' willingness to offer assistance at all times to students and availability of feedback on students learning. Farahmandian, Minavand and Afshardost et al. (2013) explored quality assurance issues in Malaysia and discovered that instructional quality did not relate to student satisfaction. Further, Tuan (2012) examined quality assurance strategies in Vietnam. The study revealed that appropriate services performed by administrative staff was positively connected to how students were satisfied. The findings show that the know-how, skills and attitude of administrative and teaching staff played a major role in telling the extent to which students were satisfied. Stukalina (2014) trying to identify determinants of students' satisfaction for educational services discovered, technological, instructional, executive and psychological environments. Razinkina et al. (2018) explored students' satisfaction as element of quality education monitoring in Rusia. Investigation discovered that awareness of certain separate elements of academic programs, especially, those that have undergone innovative changes make students satisfied. Osman and Saputra (2019) explained that the teaching method used by lecturers can be seen as an indicator of program quality in which it has a significant effect on student satisfaction. Recently, Muhsin et al. (2020) also examined the connection between university governance, teaching quality of university lecturers and students' satisfaction. The study revealed that teaching quality of lecturers, learning facilities and good university governance had a positive and significant impact on students' satisfaction. Other existing studies done in academic institutions in, Ghana, Ethiopia and South Africa showed that students were unsatisfied with academic experience quality (Ghadamosi and De Jager 2009; Gyamfi, Agyeman and Otoo 2012; Takaro 2014). Some of these studies cited above mentioned unfriendly nature of student-lecturer relationship and poor university infrastructure as possible causes of dissatisfaction. Clearly, the foregoing studies' 
findings point to the fact that, existing research about educational quality (quality assurance issues) were examined along the lines of satisfaction of students (Arokiasamy and Abdullah 2012; Yadav 2012). However, findings have not been conclusive on the indicators that significantly explain students' satisfaction. The current study contributes to this debate by exploring technological, instructional and psychological environments contribution in explaining students' satisfaction in the Ghanaian context.

\section{RESEARCH METHODS}

Descriptive cross-sectional survey design was applied in the conduct of this study. The study sought to establish indicators that predict students' satisfaction of educational service quality. In line with this aim, students in three traditional universities were randomly selected from a list of nine public autonomous universities in Ghana. The study targeted undergraduate students. Respondents were drawn from the Education Departments for the three selected universities. The Education Departments were used because the three schools have similar programmes for both undergraduate students hence students share similar characteristics in terms of their expectations of educational services quality. Convenient sampling procedure was used to take 1500 undergraduate students from all the three selected universities to serve as respondents of the study. Two instruments were used. Academic life satisfaction scale developed, pilot tested by the researcher and used to measure respondents' overall satisfaction. It was a unidimensional scale with eight items with a reliability coefficient of .80 . The second instrument used was a 19-items quality assurance questionnaire for students adapted from Stukalina (2014). The questionnaire had three hypothetical subdimensions, that is: Technological Environment (TechEnv) dimension; which measures students' views about availability, adequacy and access to modern technologies within their learning context. The second dimension: Instructional Environment (InstEnv); measures students' views about classroom situation and lecturers' approach to teaching and learning in the lecture room. Psychological Environment (PsychEnv) which measures how students' feel they belong to academic family was the third dimension. The instruments were pilot tested using 100 undergraduate University of Education, Winneba, sandwich education students. The pilot test exercise was purposely done to finetune the instrument and to test the practicality of the main data collection exercise (Amedahe 2002). Eight (8) weeks were used for the main data gathering exercise. Prior to the data collection exercise, all ethical procedures were followed, specifically, respondents were assured of confidentiality and anonymity in addition to signing of a consent form. Data to answer the research question was analysed using mean and standard deviation. However, in testing for the hypotheses and validating the instruments, Covariance-Based 
structural equation modeling approach, specifically, Analysis of Moment Structures (AMOS) was used.

\section{RESULTS OF THE STUDY}

The results of the study are presented in two parts. The first part emphasises the measurement model where Confirmatory Factor Analysis (CFA) was used while the second aspect also concentrated on the structural model to address the hypothesis raised. The level of respondents' satisfaction was also checked using mean and standard deviation.

A confirmatory factor analysis was conducted to inspect the goodness of fit of the model. The likelihood ratio Chi-square test (CMIN/Df) was 2.0, the Comparative Fit Index that is CFI was .90 , even though not up to the standard required of above .95 , it was good. The other important indicator which is RMSEA was .06 , all other factors were statistically significant $(\mathrm{p}<.05)$. All recommended fit indices met the recommended cut off by Civelek (2018), and so model fit was judged appropriate. Item loading for each of the dimensions were also inspected. Most of the items had loadings ranging from the recommended .25 to .54 which is deemed appropriate (Pallant 2011). However, the four items that recorded loadings below the recommended .25 were removed. The instrument had an overall reliability of approximately .7 , which is good.

The study also checked for convergent and discriminant validity. Average variance extracted (AVE) computed for each of the dimensions were TechEnv .53, InstEnv .56, PsychEnv .62 and SatServ .50. All these indices matched with Hair et al. (2012) recommended .50 for convergent validity. Further, the Fornell-Larcker (1981) criterion was used to assess the discriminant validity between the constructs. The results show that inter-construct correlations coefficients are lesser than the squared root of the AVE's hence the instrument met the assumption for a discriminants validity (Refer to Table 1).

Table 1: Discriminant validity

\begin{tabular}{|l|c|c|c|c|}
\hline Dimensions & TechEnvt & InstEnvt & PsychEnvt & SatServices \\
\hline TechEnvt & $(.73)$ & & & \\
\hline InstEnvt & .15 & $(.75)$ & & \\
\hline PsychEnvt & .27 & .34 & $(.79)$ & \\
\hline SatServices & .09 & .02 & .12 & $(.71)$ \\
\hline
\end{tabular}

Values in parentheses are square roots of AVE's

What this means is that the indicators of the various constructs represent individual construct different from others in the model. Based on this, the scale (instrument) can be used as a multidimensional. An examination of content validity was also done by a panel of five expert in the field of measurement and evaluation, and they unanimously indicated that the factors 
captured to represent each of the constructs are different and nomologically valid (Zhang, Dong and Wang 2010). All in all, the conclusion that can be drawn is that the model constructs are reliable and valid which can stand on their own as separate constructs hence it makes sense to further investigate the structural model.

RQ1: What is the level of students' satisfaction of educational services?

The research question sought to find out the satisfaction level of respondents concerning the educational services that they receive on the university campuses.

Table 2: Students satisfaction of educational services

\begin{tabular}{|l|c|c|}
\hline \multicolumn{1}{|c|}{ Statements } & Mean & Std. \\
\hline $\begin{array}{l}\text { My university staff are committed to deliver best services to } \\
\text { students. }\end{array}$ & 3.0 & .97 \\
\hline The university deals with students' problems promptly. & 3.1 & .96 \\
\hline I feel safe when I am on my university campus. & 2.7 & 1.1 \\
\hline $\begin{array}{l}\text { All relevant educational services (e.g. lectures and library services) } \\
\text { are provided immediately as needed. }\end{array}$ & 3.0 & .95 \\
\hline My university is committed to service schedule. & 2.8 & .99 \\
\hline The behaviour of staff and teachers make students more confident. & 2.7 & 1.0 \\
\hline My university facilities are modern and advanced. & 2.8 & 1.0 \\
\hline $\begin{array}{l}\text { I am satisfied with the kind of lecturers that we have, they represent } \\
\text { quality. }\end{array}$ & 2.8 & 1.0 \\
\hline How assessments are done in my school are fair and transparent. & 2.8 & 1.0 \\
\hline $\begin{array}{l}\text { All in all, policies of my school really support student learning and } \\
\text { growth academically. }\end{array}$ & 2.9 & 1.0 \\
\hline Mean of Means & 2.9 & .99 \\
\hline
\end{tabular}

Results (in Table 2) reveals that respondents are satisfied with the educational services that they get from their various university campuses. This is shown by the mean of means score of 2.9 which exceeds the average mean of 2.5 for the scale. Also, the standard deviation score of .99 suggests homogeneous response fashion. For purposes of illustration to the foregoing claim, respondents agreed $(\mathrm{M}=3, \mathrm{SD}=.97)$ that their university staff are committed to delivering best educational services to students. Respondents also agreed $(\mathrm{M}=3.1, \mathrm{SD}=.96)$ that their universities deal with students' problems promptly. On the issue of campus safety, respondents agreed $(\mathrm{M}=2.7, \mathrm{SD}=.99)$ that they are satisfied because they feel safe. Moreover, when respondents were asked whether relevant educational services such as library and teaching services are provided immediately as needed, the respondents agreed $(\mathrm{M}=3, \mathrm{SD}=.95)$. Further, respondents agreed $(\mathrm{M}=2.8, \mathrm{SD}=1.0)$ that they find assessment procedures fair and transparent. Finally, respondents responded in affirmation $(\mathrm{M}=2.9, \mathrm{SD}=1)$ that all in all, the academic polies of their universities are student-friendly. Clearly, the respondents (students) have shown appreciable level of satisfaction through their responses to the items of the scale. 


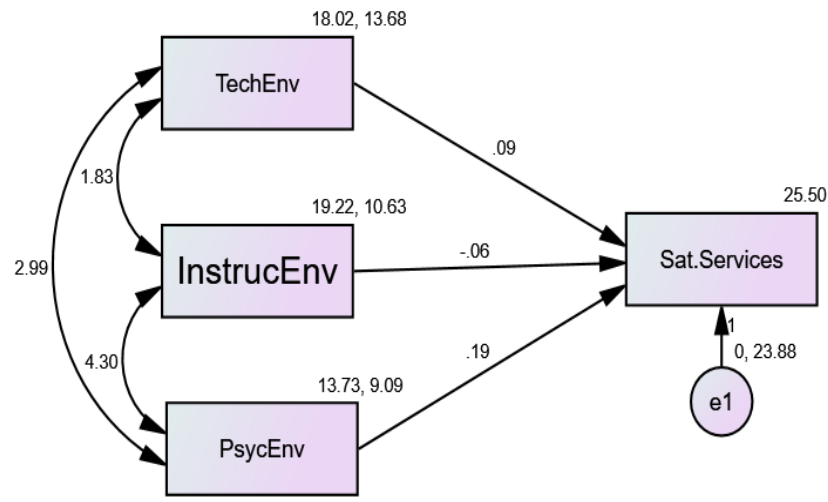

Figure 1: Path Coefficients

Table 3: Structural Regression Model

\begin{tabular}{|l|c|c|c|c|c|}
\hline \multirow{2}{*}{ Model } & \multirow{2}{*}{ B } & \multirow{2}{*}{ Std. Error } & \multirow{2}{*}{ CR } & \multicolumn{2}{c|}{ 95\% Confidence Interval } \\
\cline { 5 - 6 } & & & & Lower & \multicolumn{2}{c|}{ Upper } \\
\hline (constant) & 25.499 & 12.14 & 2.10 & 22.431 & 28.787 \\
\hline TechEnv $\rightarrow$ SatServices & $.087^{*}$ & .041 & 2.12 & .080 & .215 \\
\hline InstEnv $\rightarrow$ SatServices & $-.063^{*}$ & .031 & -2.03 & -.051 & -.209 \\
\hline PsychEnv $\rightarrow$ SatServices & $.192^{*}$ & .082 & 2.34 & .031 & .354 \\
\hline
\end{tabular}

${ }^{*}$ Significant, $p<.05, R=.02$

$\mathrm{H}_{0}$ : Technological environment does not significantly predict students' satisfaction of educational services.

This hypothesis sought to establish whether technological environment created within the selected universities predicts satisfaction of educational services. Results from Table 3 shows that Technological Environment significantly predicts satisfaction of educational services $[\mathrm{B}=$ $.087, \mathrm{CR}=2.12$, BootCI $(.080, .215)]$. The null hypothesis that suggests that technological environment does not predict satisfaction of educational services was therefore rejected in favour of its corresponding working hypothesis.

$\mathrm{H}_{0}$ : Instruction environment does not significantly predict students' satisfaction of educational 
services.

The aim was to find out whether Instructional Environment significantly predict satisfaction of educational services. Results from Table 3, revealed that Instructional Environment significantly predicts satisfaction of educational services $[\mathrm{B}=-.063, \mathrm{CR}=-2.03$, BootCI(-.051, -.209 )]. The null hypothesis that says that Instruction Environment does not significantly predict satisfaction of Educational services was therefore rejected.

$\mathrm{H}_{0}$ : Psychological environment does not significantly predict students' satisfaction of educational services.

Issues about Psychological Environment was also explored to test whether its significantly predicts satisfaction of educational services received by the respondents. Results from Table 3 , indicated that Psychological Environment significantly predict satisfaction of educational services received by respondents in the various universities $[\mathrm{B}=.192, \mathrm{CR}=2.34$, BootCI $(.031$, .354)]. The null hypothesis was therefore rejected. Independently, the three variables significantly predict students' satisfaction of educational services, however, jointly, the proportion of variance accounted for by the variables in the endogenous variable was 2 per cent.

\section{DISCUSSION}

The thrust of the study was on whether students are satisfied with the current academic services they are receiving on their school campuses. On this objective, the study findings revealed that respondents from the major three premier universities in Ghana were satisfied with the educational services that they receive. Students have the feeling that their university campuses were safe to live in, the staff of the universities were committed to their work, academic policies of the universities are student friendly, just to mention a few. This finding concurs with that of Stråhlman (2012) who found out that when students' varied needs are met through effective instruction, they become satisfied with educational services. A number of studies have also affirmed that quality educational services are linked to the satisfaction of students (Arokiasamy and Abdullah 2012; Yadav 2012; Encabo 2011; Arambewela and Hall 2009).

Further, the study findings revealed that student satisfaction for educational services can be gauged from a set of factors connected with varied aspects of the integrated educational environment (that is, technological, instructional and psychological). This is to say that the quality of an academic environment is to large extent determined by the availability and accessibility of relevant state of the art logistics that support student leaning needs (technological environment), learner-friendly and student-centered instructional approach (instructional environment) and students feeling of belongingness to the institution 
(psychological environment). The findings aligned with what Stukalina (2014) said, that is to say that in assuring quality, holistic approach to management of the educational environment of an academic institution must be adopted by managers of academic quality with special emphasis on students' satisfaction. Working on the foregoing idea, Stukalina (2014) further discovered that organizing educational resources into technological, instructional and psychological determines students' satisfaction of educational services. The findings also relate with typology of management and leadership models adapted by Bush from Bush and Glover (Bush 2003) on the issue of organization of educational resources into material, human and informational that are appreciable to client of an enterprise. The study finding emphasizes the fact that technological, instructional and psychological environment jointly has implications for students' satisfaction of educational services.

\section{CONCLUSIONS}

Students get satisfied when academic environment provides adequate technologies, meaningful instructional environment and sense of acceptance and belongingness. In other words, provision of quality educational services is a function of students' satisfaction emanating from technological, instructional and psychological environment appropriateness.

\section{RECOMMENDATIONS}

Based on the findings, the study recommends the following for policy and practice:

1. Universities in Ghana should emphasize and prioritize students' satisfaction in their quality assurance framework as a way of sustaining quality provision of educational services. Internal quality assurance practices framework should not only be focused on assessing lecturers' commitment and teaching but also students' perceptions about the learning environment, technological resources adequacy and psychological attachment of students to the academic milieu.

2. Academic institutions (especially, universities) in Ghana should continue to invest in technological infrastructure, monitor instructional dynamics and bring students closer to academic staff through students' consultative meeting in an attempt to maintain satisfaction of students.

3. Universities internal quality assurance department should assess quality educational services from the lenses of academic experience that make student satisfied. 


\section{REFERENCES}

Amedahe, F. K. 2002. Introduction to research methods. Cape Coast: Unpublished.

Afshardost, M., S. Farahmandian and S. SaqiqEshaghi. 2013. Linking trust, perceived website quality, privacy protection, gender and online purchase intentions. IOSR Journal of Business and Management 13(4): 63-72.

Arambewela, R. and J. Hall. 2009. An empirical model of international student satisfaction. Asian Pacific Journal of Marketing and Logistics 21(4): 555-569.

Arokiasamy, A. and A. Abdullah. 2012. Service quality and students' satisfaction at higher learning institutions: A case study of Malaysian university competitiveness. International Journal of Management and Strategy 3(5): 1-16.

Badu-Nyarko, S. K. 2013. Quality assurance measures in distance learning at university of Ghana. African Educational Research Journal, 1(2): 126-133.

Bernhard, A. 2012. Quality assurance in an international higher education area: A case study approach and comparative analysis. Germany: Springer Fachmedien.

Boateng, J. K. 2014. Barriers to internal quality assurance in Ghanaian private tertiary institutions. Research on Humanities and Social Sciences 4(2): 1-9.

Bush, T. 2003. Theories of educational leadership and management. $3^{\text {rd }}$ Edition. London: SAGE Publications.

Bush, T. 2011. Theories of educational leadership and management. $4^{\text {th }}$ Edition. London: SAGE Publications.

Civelek, M. E. 2018. Essentials of structural equation modeling. https://digitalcommons.unl.edu/ zeabook/64

Douglas, J., A. Douglas and B. Barnes. 2006. Measuring student satisfaction at a UK university. Quality Assurance in Education 14(3): 251-267.

Encabo, H. C. 2011. Canonical correlation analysis of student perception on instructional quality and satisfaction. JPAIR Multidisciplinary Journal 6: 1-16.

Farahmandian, S., H. Minavand and M. Afshardost. 2013. Perceived service quality and student satisfaction in higher education. Journal of Business and Management 12(4): 65-74.

Fornell, C. and D. F. Larcker. 1981. Structural equation models with unobservable variables and measurement error: Algebra and statistics.

Ghadamosi, G. and J. de Jager. 2009. What you see is what you get: Service quality, students' perceptions and satisfaction at South African universities. South African Journal of Higher Education 23(5): 877-893.

Gyamfi, D. A., A. Agyeman and B. Otoo. 2012. Assessing the provision of quality students' service and satisfaction in tertiary institution in Ghana: Using Cape Coast Polytechnic as case study. Asian Journal of Business and Management Sciences 1(12): 20-32.

Hair, J. F., C. M. Ringle and M. Sarstedt. 2012. Partial least squares: The better approach to structural equation modeling? Long Range Planning 45(6): 312-319.

Kara, A. and O. W. DeShields. 2004. Business student satisfaction, intentions and retention in higher education: An empirical investigation. http://www.marketingpower.com/Community/ARC/ gated/Documents/Teaching/MEO/student_satisfaction.pdf

Kazeroony, H. 2012. The strategic management of higher education: Serving students as customers for institutional growth. USA: Business Expert Press.

Kettunen, J. 2008. A conceptual framework to help evaluate the quality of institutional performance. Quality Assurance in Education 16(4): 322-332.

Kettunen, J. 2011. Strategy and quality maps in higher education. US-China Education Review 8(2): $149-156$. 
McRoy, I. and P. Gibbs. 2009. Leading change in higher education. Educational Management Administration \& Leadership 37(5): 687-704.

Muhsin, S., A. Nurkhin, H. Pramusinto, N. Afsari and A. F. Arham. 2020. The relationship of good university governance and student satisfaction. International Journal of Higher Education 9(1).

Ofosu, E. and S. K. Fredua-Kwarteng. 2018. Exploring internal quality assurance practices at Ghana College of Physicians and Surgeons (GCPS). European Journal of Educational Social Science 3(1): 10-27.

Osman, A. R. and R. S. Saputra. 2019. A pragmatic model of student satisfaction: A viewpoint of private higher education. Quality Assurance in Education 27(2): 142-165.

Pallant, J. 2011. SPSS Survival Manual: A step by step guide to data analysis using SPSS version $18.4^{\text {th }}$ Edition. Maidenhead, Berkshire: Open University Press. http://www. allenandunwin.com/spss

Peretomode V. F. 2008. What is higher in higher education. Benin-City: Justice Jecko Press and Publishers Ltd.

Razinkina, E., L. Pankova, I. Trostinskaya, E. Pozdeeva, L. Evseeva and A. Tanova. 2018. Student satisfaction as an element of education quality monitoring in innovative higher education institution E3S Web of Conferences, 33, 03043. DOI: https://doi.org/10.1051/ e3sconf/20183303043.

Seniwoliba, J. A. 2014. Academic quality assurance practices in Ghanaian public universities: Experience from University for Development Studies. Global Educational Research Journal 2(9): $152-166$.

Seniwoliba, J. A. and R. N. Yakubu. 2015. An analysis of the quality assurance policies in a Ghanaian University. Global Educational Research Journal 4(1): 09-15.

Sharma, D. and R. Kamath. 2006. Quality in education: The quality circle way. New Delhi: Kalpaz Publications.

Shattock, M. 2003. Managing successful universities. Maidenhead: McGraw-Hill.

Stråhlman, C. 2012. Quest for quality for students: Going back to basics. In European Students' Union $E S U$, Brussels. http://www.creup.es/documentos/esu-publicaciones/ESU-quest-report.pdf

Stukalina, Y. 2014. Identifying predictors of student satisfaction and student motivation in the framework of assuring quality in the delivery of higher education services. Business, Management and Education 12(1): 127-137.

Takaro, G. S. 2014. Measuring service quality and students' satisfaction: A case study on Hawassa University. International Journal of Business and Management 2(3): 1-16.

Tsevi, L. 2014. Private higher education's quality assurance in Ghana. International Higher Education 75: 22-24.

Tuan, N. 2012. Effects of service quality and price fairness on student satisfaction. International Journal of Business and Social Science 3(19): 132-150.

Wissema, J. G. 2009. Towards the third-generation university: Managing the university in transition. UK: MGP Books Ltd.

World Bank. 2004. Improving tertiary education in Sub-Sahara Africa: Things that work. Report of a regional training conference, Accra, Ghana.

Yadav, J. I. 2012. Service quality towards student satisfaction: An empirical investigation in selected management institutions of Sangli City. Ninth AIMS International Conference on Management, 1-4 January.

Zhang, F. F., Y. Dong and K. Wang. 2010. Reliability and validity of the Chinese version of the Interpersonal Reactivity Index-C. Chinese Journal of Clinical Psychology. 